\title{
A Comprehensive Study on Prospective Mind Management Sector in Bangladesh: A Case Study on ISOMETRIC Ltd.
}

ISSN: 2311-8636 (Print) ISSN: 2312-2021 (Online)

DOI prefix: 10.18034

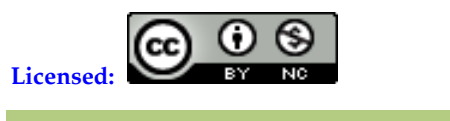

Source of Support: Nil

No Conflict of Interest: Declared

*Email for correspondence: raisulislam25@gmail.com The major objective of the study is to highlight and find out the scope and possibilities of the revelation of Mind Management industry in Bangladesh. This Study is a part of qualitative research. Here the researcher has applied observation of operational activities and procedures of services in ISOMETRIC Limited and through Questionnaires to the research Respondents. In this Study Observation is used for judgmental Assumption and Questionnaires is used for Practical, Logical and Analytical purpose. The study findings revealed that maximum people like to manage their stress through listening song and mediation or prayer and most of the people think there is no contradicts between mind management course and religion.

Key Words: Mind Management, Mind Science, Meditation

\section{INTRODUCTION}

Mind Management is an important and essential issue for the present time in Bangladesh. Mind management is very helpful for attitude control. This attitude control is essential to build SONAR BANGLA. Day by day stress, anxiety, uncertainty and insomnia are taking place in the daily life of the citizens of Bangladesh. People are losing their Confident. The people are losing their control among themselves and this they are losing Motivation to success and live. Now a day some firms revealed to provide the service. This industry is new for the country. This industry is also a growing industry. There are different organizations are working to provide the service like Quantum Method, Silva Method, Creative Meditation, Butthan Meditation, Sufi Meditation and so forth. Some of them are providing local Products and some of them are international Products. ISOMETRIC Ltd. renders the mind Management Product called Silva Method. Not only is that ISOMETRIC Ltd. is the first organization in Bangladesh which provides Mind Management service commercially. 


\section{LITERATURE REVIEW}

We are human being. As a human being it is natural to have their own feelings, thoughts, believes and attitudes. There is a proverb that a sound mind is a sound body. Point of views, moods and conducts affect our health and well-being. Now everybody aware of the importance of these influences on human mental health and their malady is stable with evolving conceptions of mind and body and represents a momentous modification in medication and the life sciences. (Baum \&Posluszny, 1999)

Schedlowski and Tewes (1999) wrote that: Psychoneuroimmunology explores the functional connections among the human nerves, the neuroendocrine system, and the resistant system. Although many of the communication patterns between these systems have yet to be expounded, it is already well documented that the resistant system is predisposed and focused by neurochemical signals from both the human nervous system and the endocrine system. (Schedlowski\&Tewes, 1999)

What is an attitude? Allport (1935) defined an attitude as a psychological or neural state of readiness, organized through experience, exerting a directive or vibrant effect on the individual's response to all objects and situations to which it is related. So we can define that attitude is a mind setup or a predisposition to act in a precise way due to both an individual's experience and personality.

Formation of attitude is an outcome of learning, modeling others, and our interpersonal communicational experiences with people and facing different situations. As a part of the society and human natures it is very common that attitudes influence our decisions, guide our behavior, and impact what we selectively remember (not always the same as what we hear). The outcome of attitudes is also very different. It comes in different strengths, and like most things that are learned or influenced through life experience, they can be measured and they can be changed. Observation and perception is closely related to attitudes. Perception is the process by which organisms illustrate and unify sensation to produce an evocative experience of the world. (Lindsay \& Norman, 1977).

According to Klinic Community Health Centre (2010) Stress is a fact of everyday life. When people reach out for help, they are often dealing with circumstances, situations and stressors in their lives that leave them feeling emotionally and physically overwhelmed. Many people feel that they have very little resources or skills to deal with the high levels of stress they are experiencing. There are four basic sources of stress-The Environment, Social Stressors, Physiological, and Thoughts.

Anxious thoughts are future oriented and often predict catastrophe. Anxious thoughts often begin with, "What if..." and end with a disastrous outcome. Anxious thoughts frequently include images of danger as well. (Klinic Community Health Centre -2010)

Marc I, and et al. (2011) said that Mind-body interventions like yoga or hypnotherapy may be effective for reducing anxiety. These can be learned to induce mental relaxation and alter negative thinking related to fretfulness to change the perception of a stressful event, leading to better adapted behavior and coping skills. Their effectiveness for treatment or prevention of women's anxiety during pregnancy needs to be confirmed in clinical trials, as anxiety during the different stages of pregnancy can affect women's health and have consequences for the child.

Awareness and receiving of the stimuli play an imperative role in the perception progression. Stimuli Receptiveness is highly eagle-eyed and may be limited by a person's 
lifetime achievement of beliefs, attitude, motivation, and personality (Assael, 1995). The most significant Critical Success Factor for effective risk management is the one most often lacking: an appropriate and mature risk culture (Hillson, 2002a). Research and experience both designate that the attitude of individuals and organizations has a significant influence on whether risk management delivers what it promises (Hillson \& MurrayWebster, 2005).

One more factor is taken in consideration however, namely perception. Both "risk" and "attitude" are influenced by perception (Tversky \& Kahneman, 1974; Kahneman \& Tversky, 1979; Kahneman et al., 1986; Lopes, 1987; Slovic, 2000; Gilovich et al., 2002; Slovic et al., 2004), including rational situational elements (such as familiarity, manageability, proximity or propinquity), subconscious heuristics operating at both individual and group level (for example availability, groupthink, or risky/cautious shift), and emotions. The influence of perception on risk affects the answers to such questions as "How uncertain is it? And how much does it matter?" Proper mind management collaborated with the entire task.

\section{SIGNIFICANCE OF THE STUDY}

The study is an empirical one and significant because it is written on a new area of business segments in Bangladesh. And the importance of this sector is described in brief as under: -

- This report helps to set up mind management business.

- Mind Management not only a business sector but also an area of a societal development of Bangladesh.

- A proper Mind Management system can change the attitude of Bangladeshi.

- A sound minded society gives a strong and stable economy.

\section{LIMITATION OF THE STUDY}

Despite all out co-ordination from the officials, the researcher has faced some limitations. This study has its limitations in some areas. The main problems the researcher has faced in preparing the paper was the inadequacy and lack of availability of required data. This report is an overall view of Mind Management thinking of Dhaka City. But there are some limitations for preparing this report. These barriers, which make hinder this study, are as follows:

- Difficulty in accessing latest data of internal operations of the Company- ISOMETRIC Ltd.

- Learning \& gathering experience of all the Mind Management functions was not stress-free.

- Another limitation of this report is the Organization failed to provide all the required information.

- $\quad$ Large-scale research was not possible due to time constraints.

- Latest data is not found in a systematic way.

Besides all of this limitation the author tried his best to make this report as best as possible.

\section{OBjectives}

- The major goal of the study is to highlight and find out the scope and possibilities of the revelation of Mind Management industry in Bangladesh. 
- To pinpoint the Services, Tools those the citizens of Bangladesh want to manage their mind.

- To identify the perception regarding mind management and evaluate the response about mind management of the Bangladeshi.

- To find out their mind management and attitude control correlation.

- To identify satisfaction level, the popular marketing strategy of this industry and the average mind management expenditure budget of the citizens of Dhaka City.

\section{Methodology of the Study}

\section{Sampling}

There is no any change in the rules and regulations related Mind Management and consultancy business in the period of April to July 2015 in Bangladesh. It is also assumed that there is concealed demand amount more than $80 \%$ within the people of the citizen of Dhaka for Mind Management and Mind Management is a growing industry.

In this study, both quantitative and qualitative method of research has been undertaken to gain insights and understanding of the overall Mind Management activities and it has also some demand in Bangladeshi citizens. After that a more comprehensive \& conclusive research has been pursued to fulfill the main purpose of the study.

The data for this study were collected and analyzed from many sources. Primary information were collected by,

- Questionnaire to the research Respondent;

- Direct communication with ISOMETRIC officials;

- Interpersonal and group communication with clients;

- Exposure on different desk of the Organization;

- Daily Diary.

Secondary data were collected by,

- Different Report of ISOMETRIC Ltd (2009-2013);

- Periodicals published by the ISOMETRIC Ltd.;

- Publications regarding Mind Science/Management;

- Prior Research Report;

- From Newspapers and Internet;

- Official Records of ISOMETRIC Limited.

\section{Procedures Employed}

- Data collected from both primary and secondary sources;

- Data analyzed in quantitative;

- Use of Table and Graph;

- Data were collected based on Survey method.

\section{THE ISOMETRIC LIMITED}

The ISOMETRIC Limited is the pioneer mind management firm in Bangladesh. In 1990, the Great Silva Guru Mahee Quazi established the firm. This is the firm that renders first mind management course in Bangladesh (By scientific Meditation Method). The 
ISOMETRIC Ltd. Offers International Mind Management course named Silva Mind Control Method. This firm is only authorized in Bangladesh \& Nepal to promote this mind control method by the Headquarter (Silva International) situated in Laredo, Texas, USA. After the transformation (death) of Mahee Quazi the firm was under the responsibility of his wife Mrs. Rowshan Hameed Quazi from 2007 to 2008. From 2008 another visionaries Mr. Sayeed-Ur-Rahman is the country director and Managing Director of this firm.

\section{Mind Management and Bangladesh}

\section{MIND MANAGEMENT}

Mind Management is the system of managing someone's brain frequency. It refers the activities in a different state of mind or brain frequencies. Scientists of the all over the world cannot find the location of mind yet. So, the mind management is the managing brain on accordance with the Intention (consciousness) programming by following a uniform way. Mind management is very widespread for Stress management.

Mind Science: Mind science is the science that deals with managing brain frequencies. But it is little different from psychology. The human brain has two hemisphere- right brain and left brain hemisphere. Left brain hemisphere deals with all logical function, math, query, and so on. Another side right brain hemisphere deals with emotional and inventive function. Mind science ensures balanced hemispheres. A balanced brain function is the core value of mind science. Visualization and Imagination is the leading key of the mind science. Jose Silva developed modern mind science; he is the pioneer who developed the method how the brain can function in different level of brain frequencies (Alpha, Theta, etc.) by the research of 20 years from 1944 to 1964 in Laredo, Texas, USA.

Meditation: Meditation is the key of Mind Management (control) Method. Meditation is the technique to focus on something. Meditation is a mode of practice in which a single trains the mind or induces a mode of awareness, either to realize some advantage or as an end in itself. The term meditation refers to a comprehensive variety of practices (much like the term sports) that includes techniques designed to endorse relaxation, build inner energy or life force (qi, ki, prana, etc.) and cultivate compassion, love, patience, generosity and forgiveness. A predominantly aspiring form of meditation aims at smoothly continued single-pointed absorption singlepointed analysis, meant to enable its practitioner to enjoy an indestructible sense of well-being while engaging in any life activity. Though mediation is very widespread and the technique is generally used by different religion. In the global world it is the basic and vigorous procedure for controlling the mind.

\section{WHY MIND MANAGEMENT}

In human mind day by day tension, frustration, pessimism is increasing. Their thought, activities and commitment are going to be unbalanced. Moreover, their thought is becoming full of negativity, fear, uncertainty, etc. They are losing their confidence; they are losing their inner values as well as outer values. If they control or maintain balance on their thought and activities, they will lead passion full and joyful life. So, mind management is very imperative.

Mind Management for Attitude Change: Attitude is the core of one's character. Everyone welcomed positivity. Attitude to other people, attitude to nature or the environment, attitude to government policy, attitude to different rules and regulations, attitude to 
anything depends on mind. But, a long time negative belief effects on attitude, it leads to do negativity. To change someone's negative attitude into positive $s /$ he must change his/her belief system through mind management. So, mind management is very essential to change or to modify or control attitude.

Mind Management and Stress Management: Stress or tension is a common word that is uttered by the all age and all area's people. This stress effects on their job and their daily activities. It makes them imbalance. Not only has that it caused to lose their sleep (Insomnia). For this reason, they become crazy. To life live peaceful, this stress must be managed. In this regards, Mind management courses help them to manage their stress effectively.

Mind Management and Education: A proper education achieved when mind and body are in relaxes. When mind is nomadic here to there, it is very tough to study. Not only that a convinced mind help to study. A mindful study is essential to establish a sustainable education in someone's mind. An experiment shows that, the study in deeper brain frequency is very operative. So, mind management is very important in case of effective education.

Mind Management and Religion: Concentration is the vital point for every religious ritual. When someone's mind is under control and cool, $\mathrm{s} /$ he can easily concentrate in their daily religious ritual activities. So, mind management is a supportive fact to practice religious ritual activities.

Mind Management and Business: Motivation is the main essence for the Businessperson and for his/her personnel. Without motivation there is no charm in the business. So, the success of the business is delayed. Motivation is the task of mind. If we want to gear up the motivation, we must manage our mind. Not only is that, to keep a cool mind and favorable mental preparation for conducting business Mind Management essential.

Mind Management and Pregnant Women: When a woman is pregnant she thought, imagination and activities directly affect her baby in her womb. This is scientifically and religiously proved that, a pregnant woman can't act like her regular life as normal she led previous. She is in a different experience. Her food habit, communicational pattern, regular daily life has become change. So, it badly needs to manage her mind for herself and her desired baby.

\section{DIFFERENT METHOD IN BANGLADESH}

Mind management method is the new industry in Bangladesh. There are different firms or organizations are working for rendering mind management service in this country. Some of them deal local products, and some of them deal International products.

Silva Method: Silva Method is the first scientific Mind Control Method in Bangladesh which is launched by Great Silva Guru Mahee Quazi in 1990 (ISOMETRIC Ltd.). Most of the mind control method's promoters who are running their operation in Bangladesh are the students of Mahee Quazi. José Silva of Laredo, Texas, USA developed the self program named Silva Method. The Silva Method spreads knowledge to their students and guided imagery techniques to "rewire" their subconscious and negative programming, tap into their true potential and achieve their goals through a meditation technique. This method also offered mental training program in over 129 countries around the world. It claims to increase an individual's 
abilities and sense of personal well-being through relaxation and development of their higher brain functions. It also help to improve a person's self-image, allow them to think in a clearer manner, and assist people in overcoming conditions such as nicotine addiction. ISOMETRIC Ltd. is the only authorized organization which promotes Silva Method in Bangladesh and Nepal.

Quantum Method: On the other hand, Quantum Method Meditation Course is a four-day course that provides basic training named the 'science of living'. It is pooled with the meditation techniques and life principles that will bring peace, health, happiness and success to human life. From the very beginning, the course has been enormously successful and popular in Bangladesh. 70 year old men and 12 year old children, professors and students, artists and religious leaders, politicians and journalists, housewives and teenagers, professionals and frustrated job seekers, famous celebrities and ordinary workers all sit together and take part in the course. Quantum method is very effective course and it is verified, the people of age-old are the main follower of the method. They follow the method for spiritual calmness and mental consummation.

Other Mind Management Method: There are many methods in Bangladesh which are rendering mind management service. Some of them are:

- Silva Ultra mind ESP

- Creative Meditation

- Sufi Meditation

- Reiki

- Butthan Meditation

But among them, Silva Method and Quantum Method are most popular mind management method in Bangladesh.

\section{ISOMETRIC LTD. - MIND MANAGEMENT SYSTEM}

In 1966 JOSE SILVA, a Spanish-American Scientist invented a unique STRESS MANAGEMENT SYSTEM known as "THE SILVA METHOD". It was an outcome of his long 22 years of research and experiments from 1944 to 1966 costing \$5, 00,000 of 1960's monetary value equivalent to $\$ 2$ million in today's value. This method is now taught in 129 countries across the globe in 36 different languages.

In 1990, MAHEE QUAZI, founded ISOMETRIC and introduced "The Silva Method" for the first time in Bangladesh. It was the dawn of Mind Science in this country.

ISOMETRIC, the sole official representative of "The Silva Method" in Bangladesh, is conducting the courses in the country since inception. At present, it is solely representing "The Silva Method" in Bangladesh and Nepal. ISOMETRIC conducts the course all over the country in Bengali.

After departure of MAHEE QUAZI his wife MRS. RAWSHAN MAHEE QUAZI became the Country Director of ISOMETRIC and in 2008 she handed over the Country Directorship to MR. SAYEED-UR-RAHMAN. Since then he is discharging the responsibilities in Bangladesh and Nepal.

\section{Courses}

ISOMETRIC Ltd. provides International Mind Management course. It offers two international courses named "Silva Life System" and "Silva Intuition System". Silva Life 
System (SLS) is related to the self-empowerment and self-esteem establishment program. Another side, Silva Intuition System (SIS) enables someone to operative use of ESP (sixth sense) and increase the power of telepathy. Moreover, ISOMETRIC Ltd. arranges-

- Seminar

- Workshop

- Conference

- Get-together

- Session

- Counseling

- Corporate motivation

Core Analysis of Mind Management Sector of Bangladesh

Mind Fitness Center by Age

\begin{tabular}{|c|c|c|c|c|c|}
\hline \multicolumn{6}{|c|}{ Age of the respondents ${ }^{*}$ Mind fitness center Cross tabulation } \\
\hline & & & \multicolumn{2}{|c|}{ Mind fitness center } & \multirow[t]{2}{*}{ Total } \\
\hline & & & Yes & No & \\
\hline \multirow{15}{*}{$\begin{array}{l}\text { Age of the } \\
\text { respondents }\end{array}$} & \multirow[t]{3}{*}{$15-20$} & Count & 4 & 0 & 4 \\
\hline & & $\begin{array}{l}\% \text { within Age of the } \\
\text { respondents }\end{array}$ & $100.0 \%$ & $.0 \%$ & $100.0 \%$ \\
\hline & & $\%$ within Mind fitness center & $8.3 \%$ & $.0 \%$ & $8.0 \%$ \\
\hline & \multirow[t]{3}{*}{$21-30$} & Count & 27 & 2 & 29 \\
\hline & & $\begin{array}{l}\% \text { within Age of the } \\
\text { respondents }\end{array}$ & $93.1 \%$ & $6.9 \%$ & $100.0 \%$ \\
\hline & & $\%$ within Mind fitness center & $56.2 \%$ & $100.0 \%$ & $58.0 \%$ \\
\hline & \multirow[t]{3}{*}{$31-40$} & Count & 11 & 0 & 11 \\
\hline & & $\begin{array}{l}\% \text { within Age of the } \\
\text { respondents }\end{array}$ & $100.0 \%$ & $.0 \%$ & $100.0 \%$ \\
\hline & & $\%$ within Mind fitness center & $22.9 \%$ & $.0 \%$ & $22.0 \%$ \\
\hline & \multirow[t]{3}{*}{$41-50$} & Count & 4 & 0 & 4 \\
\hline & & $\begin{array}{l}\% \text { within Age of the } \\
\text { respondents }\end{array}$ & $100.0 \%$ & $.0 \%$ & $100.0 \%$ \\
\hline & & $\%$ within Mind fitness center & $8.3 \%$ & $.0 \%$ & $8.0 \%$ \\
\hline & \multirow[t]{3}{*}{ 51-Above } & Count & 2 & 0 & 2 \\
\hline & & $\begin{array}{l}\% \text { within Age of the } \\
\text { respondents }\end{array}$ & $100.0 \%$ & $.0 \%$ & $100.0 \%$ \\
\hline & & $\%$ within Mind fitness center & $4.2 \%$ & $.0 \%$ & $4.0 \%$ \\
\hline \multirow{3}{*}{\multicolumn{2}{|c|}{ Total }} & Count & 48 & 2 & 50 \\
\hline & & $\begin{array}{l}\% \text { within Age of the } \\
\text { respondents }\end{array}$ & $96.0 \%$ & $4.0 \%$ & $100.0 \%$ \\
\hline & & $\%$ within Mind fitness center & $100.0 \%$ & $100.0 \%$ & $100.0 \%$ \\
\hline
\end{tabular}

Fig. 1: Mind fitness center needed by Age

Analysis: Maximum people want mind fitness center for managing their mind especially who are growing old they think mind fitness center is an essential thing. The people of (21-30) years less desire it than others. The people of this age range pass their golden age of their life. They feel less pressure than above of the age range. Social, conjugal relation, the financial problem are arises on older age than middle age. 
Mind Fitness Center by Occupation

\begin{tabular}{|c|c|c|c|c|c|}
\hline \multicolumn{6}{|c|}{ Occupation of the respondents * Mind fitness center Cross tabulation } \\
\hline & & & \multicolumn{2}{|c|}{ Mind fitness center } & \multirow[t]{2}{*}{ Total } \\
\hline & & & Yes & No & \\
\hline \multirow{14}{*}{$\begin{array}{l}\text { Occupation of } \\
\text { the respondents }\end{array}$} & \multirow{2}{*}{$\begin{array}{c}\text { Government } \\
\text { Official }\end{array}$} & Count & 9 & 0 & 9 \\
\hline & & $\begin{array}{l}\% \text { within Occupation } \\
\text { of the respondents }\end{array}$ & $100.0 \%$ & $.0 \%$ & $100.0 \%$ \\
\hline & \multirow{2}{*}{$\begin{array}{l}\text { Self-Own } \\
\text { Business }\end{array}$} & Count & 4 & 1 & 5 \\
\hline & & $\begin{array}{l}\% \text { within Occupation } \\
\text { of the respondents }\end{array}$ & $80.0 \%$ & $20.0 \%$ & $100.0 \%$ \\
\hline & \multirow{2}{*}{$\begin{array}{l}\text { Private } \\
\text { Sectors }\end{array}$} & Count & 12 & 1 & 13 \\
\hline & & $\begin{array}{l}\% \text { within Occupation } \\
\text { of the respondents }\end{array}$ & $92.3 \%$ & $7.7 \%$ & $100.0 \%$ \\
\hline & \multirow[t]{2}{*}{ Employees } & Count & 2 & 0 & 2 \\
\hline & & $\begin{array}{l}\% \text { within Occupation } \\
\text { of the respondents }\end{array}$ & $100.0 \%$ & $.0 \%$ & $100.0 \%$ \\
\hline & \multirow[t]{2}{*}{ Student } & Count & 15 & 0 & 15 \\
\hline & & $\begin{array}{l}\% \text { within Occupation } \\
\text { of the respondents }\end{array}$ & $100.0 \%$ & $.0 \%$ & $100.0 \%$ \\
\hline & \multirow{2}{*}{$\begin{array}{l}\text { House } \\
\text { wife }\end{array}$} & Count & 3 & 0 & 3 \\
\hline & & $\begin{array}{l}\% \text { within Occupation } \\
\text { of the respondents }\end{array}$ & $100.0 \%$ & $.0 \%$ & $100.0 \%$ \\
\hline & \multirow[t]{2}{*}{ Others } & Count & 3 & 0 & 3 \\
\hline & & $\begin{array}{l}\% \text { within Occupation } \\
\text { of the respondents }\end{array}$ & $100.0 \%$ & $.0 \%$ & $100.0 \%$ \\
\hline \multirow{2}{*}{\multicolumn{2}{|c|}{ Total }} & Count & 48 & 2 & 50 \\
\hline & & $\begin{array}{l}\% \text { within Occupation } \\
\text { of the respondents }\end{array}$ & $96.0 \%$ & $4.0 \%$ & $100.0 \%$ \\
\hline
\end{tabular}

Fig. 2: Mind fitness center needed by different profession

Analysis: Maximum people (96\%) wants mind fitness center for managing their mind. A government official, Employees, Students, and housewife, want it more than private sectors and businessperson. Some students say they need mind freshness for removing their mental stress of class, exam, assignment, term paper \& so on. Employees express that they want mind fitness because they have to do the same routine job, they feel boring. Again women especially homemakers show very interest on mind fitness center. Government official says they are doing less creative and droning job, it affects their mind. So, Mind Fitness Center is a desire of the mass people of the country.

Relation between Mind and Body

\begin{tabular}{|c|c|c|c|c|}
\hline \multicolumn{6}{|c|}{ Relation between Mind \& Body } \\
\hline & Frequency & Percent & Valid Percent & Cumulative Percent \\
\hline Middle & 5 & 10.0 & 10.0 & 10.0 \\
\hline Closer & 33 & 66.0 & 66.0 & 76.0 \\
\hline Tight & 12 & 24.0 & 24.0 & 100.0 \\
\hline Total & 50 & 100.0 & 100.0 & \\
\hline
\end{tabular}

Fig. 3: Relation between Mind \& Body 
Analysis: Most of the people (66\%) think the affiliation between Mind and Body is Closer. Then next maximum (24\%) people think this relation is tight. But the very tiny portion of people believes this connection is middle. And there is no any person they think there is a detached relationship between mind and body. So, they believe if they spend money for marinating their physical health but why not to their Mind.

\section{Hear about Mind Management Course}

\begin{tabular}{|l|c|c|c|c|}
\hline Hear about mind management course & Frequency & Percent & Valid Percent & Cumulative Percent \\
\hline Press Advertisement & 9 & 18.0 & 18.0 & 18.0 \\
\hline Television Advertisement & 1 & 2.0 & 2.0 & 20.0 \\
\hline Family/Relatives/Friends/colleagues & 40 & 80.0 & 80.0 & 100.0 \\
\hline Total & $\mathbf{5 0}$ & $\mathbf{1 0 0 . 0}$ & $\mathbf{1 0 0 . 0}$ & \\
\hline
\end{tabular}

Fig. 4: Hear about Mind Management Courses

Analysis: This finding expresses that personal marketing approach (family, friends, and colleagues) is effective in this industry than TV or Radio Commercial. But there is a little impact on Press Advertisement.

\section{Money Spent by Age Class}

\begin{tabular}{|c|c|c|c|c|c|c|}
\hline \multicolumn{7}{|c|}{ Age of the respondents * Spend for mind management Cross tabulation } \\
\hline & & & \multicolumn{3}{|c|}{ Spend for mind management } & \multirow[t]{2}{*}{ Total } \\
\hline & & & $0-1000$ & $1000-5000$ & $5000-10000$ & \\
\hline \multirow{15}{*}{$\begin{array}{l}\text { Age of the } \\
\text { respondents }\end{array}$} & \multirow[t]{3}{*}{$15-20$} & Count & 4 & 0 & 0 & 4 \\
\hline & & $\begin{array}{l}\% \text { within Age of } \\
\text { the respondents }\end{array}$ & $100.0 \%$ & $.0 \%$ & $.0 \%$ & $100.0 \%$ \\
\hline & & $\begin{array}{l}\% \text { within Spend for } \\
\text { mind management }\end{array}$ & $11.8 \%$ & $.0 \%$ & $.0 \%$ & $8.0 \%$ \\
\hline & \multirow[t]{3}{*}{$21-30$} & Count & 21 & 7 & 1 & 29 \\
\hline & & $\begin{array}{l}\% \text { within Age of } \\
\text { the respondents }\end{array}$ & $72.4 \%$ & $24.1 \%$ & $3.4 \%$ & $100.0 \%$ \\
\hline & & $\begin{array}{l}\% \text { within Spend for } \\
\text { mind management }\end{array}$ & $61.8 \%$ & $58.3 \%$ & $25.0 \%$ & $58.0 \%$ \\
\hline & \multirow[t]{3}{*}{$31-40$} & Count & 6 & 2 & 3 & 11 \\
\hline & & $\begin{array}{l}\% \text { within Age of } \\
\text { the respondents }\end{array}$ & $54.5 \%$ & $18.2 \%$ & $27.3 \%$ & $100.0 \%$ \\
\hline & & $\begin{array}{l}\% \text { within Spend for } \\
\text { mind management }\end{array}$ & $17.6 \%$ & $16.7 \%$ & $75.0 \%$ & $22.0 \%$ \\
\hline & \multirow[t]{3}{*}{$41-50$} & Count & 3 & 1 & 0 & 4 \\
\hline & & $\begin{array}{l}\% \text { within Age of } \\
\text { the respondents }\end{array}$ & $75.0 \%$ & $25.0 \%$ & $.0 \%$ & $100.0 \%$ \\
\hline & & $\begin{array}{l}\% \text { within Spend for } \\
\text { mind management }\end{array}$ & $8.8 \%$ & $8.3 \%$ & $.0 \%$ & $8.0 \%$ \\
\hline & \multirow[t]{3}{*}{ 51-Above } & Count & 0 & 2 & 0 & 2 \\
\hline & & $\begin{array}{l}\% \text { within Age of } \\
\text { the respondents }\end{array}$ & $.0 \%$ & $100.0 \%$ & $.0 \%$ & $100.0 \%$ \\
\hline & & $\begin{array}{l}\% \text { within Spend for } \\
\text { mind management }\end{array}$ & $.0 \%$ & $16.7 \%$ & $.0 \%$ & $4.0 \%$ \\
\hline \multirow{3}{*}{\multicolumn{2}{|c|}{ Total }} & Count & 34 & 12 & 4 & 50 \\
\hline & & $\begin{array}{l}\% \text { within Age of } \\
\text { the respondents }\end{array}$ & $68.0 \%$ & $24.0 \%$ & $8.0 \%$ & $100.0 \%$ \\
\hline & & $\begin{array}{l}\% \text { within Spend for } \\
\text { mind management }\end{array}$ & $100.0 \%$ & $100.0 \%$ & $100.0 \%$ & $100.0 \%$ \\
\hline
\end{tabular}

Fig. 5: Money spend by different age for mind management 
Analysis: This finding provides imperative information for marketing of mind management products. This information is essential for segmented marketing. This table shows that the age range of 31-40 spends highest. The study found that the people of this range are in more stress for their career. So, premium type of mind management program should be designed by this age range. And the average targeted age range is 21-Above.

\section{Money Spent by Occupational Pattern}

\begin{tabular}{|c|c|c|c|c|c|c|}
\hline \multicolumn{7}{|c|}{ Occupation of the respondents * Spend for mind management Cross tabulation } \\
\hline & & & \multicolumn{3}{|c|}{ Spend for mind management } & \multirow[t]{2}{*}{ Total } \\
\hline & & & $0-1000$ & $1000-5000$ & $5000-10000$ & \\
\hline \multirow{21}{*}{$\begin{array}{l}\text { Occupation of } \\
\text { the respondents }\end{array}$} & \multirow{3}{*}{$\begin{array}{l}\text { Government } \\
\text { Official }\end{array}$} & Count & 3 & 3 & 3 & 9 \\
\hline & & $\begin{array}{l}\text { \% within Occupation } \\
\text { of the respondents }\end{array}$ & $33.3 \%$ & $33.3 \%$ & $33.3 \%$ & $100.0 \%$ \\
\hline & & $\begin{array}{l}\text { \% within Spend for } \\
\text { mind management }\end{array}$ & $8.8 \%$ & $25.0 \%$ & $75.0 \%$ & $18.0 \%$ \\
\hline & \multirow{3}{*}{$\begin{array}{l}\text { Self-Own } \\
\text { Business }\end{array}$} & Count & 3 & 2 & 0 & 5 \\
\hline & & $\begin{array}{l}\text { \% within Occupation } \\
\text { of the respondents }\end{array}$ & $60.0 \%$ & $40.0 \%$ & $.0 \%$ & $100.0 \%$ \\
\hline & & $\begin{array}{l}\text { \% within Spend for } \\
\text { mind management }\end{array}$ & $8.8 \%$ & $16.7 \%$ & $.0 \%$ & $10.0 \%$ \\
\hline & \multirow{3}{*}{$\begin{array}{l}\text { Private } \\
\text { Sectors }\end{array}$} & Count & 10 & 3 & 0 & 13 \\
\hline & & $\begin{array}{l}\text { \% within Occupation } \\
\text { of the respondents }\end{array}$ & $76.9 \%$ & $23.1 \%$ & $.0 \%$ & $100.0 \%$ \\
\hline & & $\begin{array}{l}\% \text { within Spend for } \\
\text { mind management }\end{array}$ & $29.4 \%$ & $25.0 \%$ & $.0 \%$ & $26.0 \%$ \\
\hline & \multirow[t]{3}{*}{ Employees } & Count & 1 & 0 & 1 & 2 \\
\hline & & $\begin{array}{l}\% \text { within Occupation } \\
\text { of the respondents }\end{array}$ & $50.0 \%$ & $.0 \%$ & $50.0 \%$ & $100.0 \%$ \\
\hline & & $\begin{array}{l}\% \text { within Spend for } \\
\text { mind management }\end{array}$ & $2.9 \%$ & $.0 \%$ & $25.0 \%$ & $4.0 \%$ \\
\hline & \multirow[t]{3}{*}{ Student } & Count & 13 & 2 & 0 & 15 \\
\hline & & $\begin{array}{l}\text { \% within Occupation } \\
\text { of the respondents }\end{array}$ & $86.7 \%$ & $13.3 \%$ & $.0 \%$ & $100.0 \%$ \\
\hline & & $\begin{array}{l}\% \text { within Spend for } \\
\text { mind management }\end{array}$ & $38.2 \%$ & $16.7 \%$ & $.0 \%$ & $30.0 \%$ \\
\hline & \multirow[t]{3}{*}{ Housewife } & Count & 2 & 1 & 0 & 3 \\
\hline & & $\begin{array}{l}\% \text { within Occupation } \\
\text { of the respondents }\end{array}$ & $66.7 \%$ & $33.3 \%$ & $.0 \%$ & $100.0 \%$ \\
\hline & & $\begin{array}{l}\% \text { within Spend for } \\
\text { mind management }\end{array}$ & $5.9 \%$ & $8.3 \%$ & $.0 \%$ & $6.0 \%$ \\
\hline & \multirow[t]{3}{*}{ Others } & Count & 2 & 1 & 0 & 3 \\
\hline & & $\begin{array}{l}\% \text { within Occupation } \\
\text { of the respondents }\end{array}$ & $66.7 \%$ & $33.3 \%$ & $.0 \%$ & $100.0 \%$ \\
\hline & & $\begin{array}{l}\% \text { within Spend for } \\
\text { mind management }\end{array}$ & $5.9 \%$ & $8.3 \%$ & $.0 \%$ & $6.0 \%$ \\
\hline \multirow{3}{*}{\multicolumn{2}{|c|}{ Total }} & Count & 34 & 12 & 4 & 50 \\
\hline & & $\begin{array}{l}\% \text { within Occupation } \\
\text { of the respondents }\end{array}$ & $68.0 \%$ & $24.0 \%$ & $8.0 \%$ & $100.0 \%$ \\
\hline & & $\begin{array}{l}\% \text { within Spend for } \\
\text { mind management }\end{array}$ & $100.0 \%$ & $100.0 \%$ & $100.0 \%$ & $100.0 \%$ \\
\hline
\end{tabular}

Fig. 6: Money spend by different occupation for mind management 
Analysis: Employees spend more money (50\%) for their mind management than other professional. So, the mind management firm should choice this sector first. The second targeted market should be Government official, (33.33\%). Housewives, businessperson and private sectors spend average. But this market segmentation also profitable because there is a large scale scope of income on the volume basis.

\section{Tools for Stress Management}

\begin{tabular}{|c|c|c|c|c|c|c|c|c|}
\hline \multicolumn{9}{|c|}{ Occupation of the respondents * Tools for Stress Management Cross tabulation } \\
\hline & & & \multicolumn{5}{|c|}{ Tools for Stress Management } & \multirow[t]{2}{*}{ Tota. } \\
\hline & & & $\begin{array}{l}\text { Listen } \\
\text { Song }\end{array}$ & Sleep & Gossip & Meditation & Others & \\
\hline \multirow{21}{*}{$\begin{array}{l}\text { Occupation } \\
\text { of the } \\
\text { respondents }\end{array}$} & \multirow{3}{*}{$\begin{array}{l}\text { Government } \\
\text { Official }\end{array}$} & Count & 3 & 2 & 0 & 3 & 1 & 9 \\
\hline & & $\begin{array}{l}\% \text { within Occupation } \\
\text { of the respondents }\end{array}$ & $33.3 \%$ & $22.2 \%$ & $.0 \%$ & $33.3 \%$ & $11.1 \%$ & $\begin{array}{c}100.0 \\
\%\end{array}$ \\
\hline & & $\begin{array}{l}\text { \% within Tools for } \\
\text { Stress Management }\end{array}$ & $21.4 \%$ & $20.0 \%$ & $.0 \%$ & $20.0 \%$ & $33.3 \%$ & $18.0 \%$ \\
\hline & \multirow{3}{*}{$\begin{array}{l}\text { Self-Own } \\
\text { Business }\end{array}$} & Count & 0 & 1 & 2 & 2 & 0 & 5 \\
\hline & & $\begin{array}{l}\% \text { within Occupation } \\
\text { of the respondents }\end{array}$ & $.0 \%$ & $20.0 \%$ & $40.0 \%$ & $40.0 \%$ & $.0 \%$ & $\begin{array}{c}100.0 \\
\%\end{array}$ \\
\hline & & $\begin{array}{l}\% \text { within Tools for } \\
\text { Stress Management }\end{array}$ & $.0 \%$ & $10.0 \%$ & $25.0 \%$ & $13.3 \%$ & $.0 \%$ & $10.0 \%$ \\
\hline & \multirow{3}{*}{$\begin{array}{l}\text { Private } \\
\text { Sectors }\end{array}$} & Count & 2 & 2 & 2 & 7 & 0 & 13 \\
\hline & & $\begin{array}{l}\% \text { within Occupation } \\
\text { of the respondents }\end{array}$ & $15.4 \%$ & $15.4 \%$ & $15.4 \%$ & $53.8 \%$ & $.0 \%$ & $\begin{array}{c}100.0 \\
\%\end{array}$ \\
\hline & & $\begin{array}{l}\% \text { within Tools for } \\
\text { Stress Management }\end{array}$ & $14.3 \%$ & $20.0 \%$ & $25.0 \%$ & $46.7 \%$ & $.0 \%$ & $26.0 \%$ \\
\hline & \multirow{3}{*}{ Employees } & Count & 1 & 0 & 1 & 0 & 0 & 2 \\
\hline & & $\begin{array}{l}\% \text { within Occupation } \\
\text { of the respondents }\end{array}$ & $50.0 \%$ & $.0 \%$ & $50.0 \%$ & $.0 \%$ & $.0 \%$ & $\begin{array}{c}100.0 \\
\%\end{array}$ \\
\hline & & $\begin{array}{l}\text { \% within Tools for } \\
\text { Stress Management }\end{array}$ & $7.1 \%$ & $.0 \%$ & $12.5 \%$ & $.0 \%$ & $.0 \%$ & $4.0 \%$ \\
\hline & \multirow[t]{3}{*}{ Student } & Count & 6 & 4 & 2 & 2 & 1 & 15 \\
\hline & & $\begin{array}{l}\% \text { within Occupation } \\
\text { of the respondents }\end{array}$ & $40.0 \%$ & $26.7 \%$ & $13.3 \%$ & $13.3 \%$ & $6.7 \%$ & $\begin{array}{c}100.0 \\
\%\end{array}$ \\
\hline & & $\begin{array}{l}\text { \% within Tools for } \\
\text { Stress Management }\end{array}$ & $42.9 \%$ & $40.0 \%$ & $25.0 \%$ & $13.3 \%$ & $33.3 \%$ & $30.0 \%$ \\
\hline & \multirow[t]{3}{*}{ Housewife } & Count & 1 & 0 & 0 & 1 & 1 & 3 \\
\hline & & $\begin{array}{l}\% \text { within Occupation } \\
\text { of the respondents }\end{array}$ & $33.3 \%$ & $.0 \%$ & $.0 \%$ & $33.3 \%$ & $33.3 \%$ & $\begin{array}{c}100.0 \\
\%\end{array}$ \\
\hline & & $\begin{array}{l}\text { \% within Tools for } \\
\text { Stress Management }\end{array}$ & $7.1 \%$ & $.0 \%$ & $.0 \%$ & $6.7 \%$ & $33.3 \%$ & $6.0 \%$ \\
\hline & \multirow[t]{3}{*}{ Others } & Count & 1 & 1 & 1 & 0 & 0 & 3 \\
\hline & & $\begin{array}{l}\% \text { within Occupation } \\
\text { of the respondents }\end{array}$ & $33.3 \%$ & $33.3 \%$ & $33.3 \%$ & $.0 \%$ & $.0 \%$ & $\begin{array}{c}100.0 \\
\%\end{array}$ \\
\hline & & $\begin{array}{l}\% \text { within Tools for } \\
\text { Stress Management }\end{array}$ & $7.1 \%$ & $10.0 \%$ & $12.5 \%$ & $.0 \%$ & $.0 \%$ & $6.0 \%$ \\
\hline \multirow{3}{*}{\multicolumn{2}{|c|}{ Total }} & Count & 14 & 10 & 8 & 15 & 3 & 50 \\
\hline & & $\begin{array}{l}\% \text { within Occupation } \\
\text { of the respondents }\end{array}$ & $28.0 \%$ & $20.0 \%$ & $16.0 \%$ & $30.0 \%$ & $6.0 \%$ & $\begin{array}{c}100.0 \\
\%\end{array}$ \\
\hline & & $\begin{array}{l}\text { \% within Tools for } \\
\text { Stress Management }\end{array}$ & $100.0 \%$ & $\begin{array}{c}100.0 \\
\%\end{array}$ & $\begin{array}{c}100.0 \\
\%\end{array}$ & $100.0 \%$ & $\begin{array}{c}100.0 \\
\%\end{array}$ & $\begin{array}{c}100.0 \\
\%\end{array}$ \\
\hline
\end{tabular}

Fig. 7: Tools for Stress Management

Analysis: Meditation is the fundamentals of mind control. The people of private sectors use more meditation than others. The next group is businessperson, and housewife. It expresses that these groups (private sector, businessperson, and housewife) have a strong faith on meditation. Not only that these groups do more challenging jobs than other profession and face dreary situation more than others. So, these groups should be the targeted primarily for mind management organization. 


\section{Level of Satisfaction}

\begin{tabular}{|c|c|c|c|c|c|c|c|c|}
\hline \multicolumn{9}{|c|}{ Age of the respondents * Level of Satisfaction Cross tabulation } \\
\hline & & & \multicolumn{5}{|c|}{ Level of Satisfaction } & \multirow[t]{2}{*}{ Total } \\
\hline & & & \begin{tabular}{|c|} 
Very \\
Dissatisfied
\end{tabular} & \begin{tabular}{l|} 
Somewhat \\
Dissatisfied
\end{tabular} & $\begin{array}{c}\text { Neither } \\
\text { Satisfied nor } \\
\text { Dissatisfied }\end{array}$ & $\begin{array}{c}\text { Somewhat } \\
\text { Satisfied }\end{array}$ & \begin{tabular}{|c|} 
Very \\
Satisfied
\end{tabular} & \\
\hline \multirow{15}{*}{$\begin{array}{l}\text { Age of the } \\
\text { responde } \\
\text { nts }\end{array}$} & \multirow[t]{3}{*}{$15-20$} & Count & 0 & 0 & 2 & 1 & 1 & 4 \\
\hline & & $\begin{array}{l}\% \text { within Age of the } \\
\text { respondents }\end{array}$ & $.0 \%$ & $.0 \%$ & $50.0 \%$ & $25.0 \%$ & $25.0 \%$ & $100.0 \%$ \\
\hline & & $\begin{array}{l}\% \text { within Level of } \\
\text { Satisfaction }\end{array}$ & $.0 \%$ & $.0 \%$ & $9.5 \%$ & $5.6 \%$ & $33.3 \%$ & $8.0 \%$ \\
\hline & \multirow[t]{3}{*}{$21-30$} & Count & 2 & 4 & 13 & 10 & 0 & 29 \\
\hline & & $\begin{array}{l}\% \text { within Age of the } \\
\text { respondents }\end{array}$ & $6.9 \%$ & $13.8 \%$ & $44.8 \%$ & $34.5 \%$ & $.0 \%$ & $100.0 \%$ \\
\hline & & $\begin{array}{l}\% \text { within Level of } \\
\text { Satisfaction }\end{array}$ & $66.7 \%$ & $80.0 \%$ & $61.9 \%$ & $55.6 \%$ & $.0 \%$ & $58.0 \%$ \\
\hline & \multirow[t]{3}{*}{$31-40$} & Count & 0 & 0 & 5 & 4 & 2 & 11 \\
\hline & & $\begin{array}{l}\% \text { within Age of the } \\
\text { respondents }\end{array}$ & $.0 \%$ & $.0 \%$ & $45.5 \%$ & $36.4 \%$ & $18.2 \%$ & $100.0 \%$ \\
\hline & & $\begin{array}{l}\% \text { within Level of } \\
\text { Satisfaction }\end{array}$ & $.0 \%$ & $.0 \%$ & $23.8 \%$ & $22.2 \%$ & $66.7 \%$ & $22.0 \%$ \\
\hline & \multirow[t]{3}{*}{$41-50$} & Count & 1 & 0 & 1 & 2 & 0 & 4 \\
\hline & & $\begin{array}{l}\% \text { within Age of the } \\
\text { respondents }\end{array}$ & $25.0 \%$ & $.0 \%$ & $25.0 \%$ & $50.0 \%$ & $.0 \%$ & $100.0 \%$ \\
\hline & & $\begin{array}{l}\% \text { within Level of } \\
\text { Satisfaction }\end{array}$ & $33.3 \%$ & $.0 \%$ & $4.8 \%$ & $11.1 \%$ & $.0 \%$ & $8.0 \%$ \\
\hline & \multirow{3}{*}{$\begin{array}{l}51- \\
\text { Above }\end{array}$} & Count & 0 & 1 & 0 & 1 & 0 & 2 \\
\hline & & $\begin{array}{l}\% \text { within Age of the } \\
\text { respondents }\end{array}$ & $.0 \%$ & $50.0 \%$ & $.0 \%$ & $50.0 \%$ & $.0 \%$ & $100.0 \%$ \\
\hline & & $\begin{array}{l}\% \text { within Level of } \\
\text { Satisfaction }\end{array}$ & $.0 \%$ & $20.0 \%$ & $.0 \%$ & $5.6 \%$ & $.0 \%$ & $4.0 \%$ \\
\hline \multirow{3}{*}{\multicolumn{2}{|c|}{ Total }} & Count & 3 & 5 & 21 & 18 & 3 & 50 \\
\hline & & $\begin{array}{l}\% \text { within Age of the } \\
\text { respondents }\end{array}$ & $6.0 \%$ & $10.0 \%$ & $42.0 \%$ & $36.0 \%$ & $6.0 \%$ & $100.0 \%$ \\
\hline & & $\begin{array}{l}\text { \% within Level of } \\
\text { Satisfaction }\end{array}$ & $100.0 \%$ & $100.0 \%$ & $100.0 \%$ & $100.0 \%$ & $100.0 \%$ & $100.0 \%$ \\
\hline
\end{tabular}

Fig. 8: Level of Satisfaction

Analysis: This table shows very significant information. The age range of (41-50) and (51-Above) is sensitive. Both the levels express the both satisfaction and dissatisfaction. So mind management firm must to concentrate that age range to design their products. But overall condition is not contented yet. The mind management industry should focus their products more. But satisfaction level is increasing than dissatisfaction.

\section{Level of Perception}

\begin{tabular}{|l|c|c|c|}
\hline Descriptive Statistics & $\mathrm{N}$ & Mean & Std. Deviation \\
\hline Contradicts to religion & 50 & 1.64 & 1.064 \\
\hline Help to religion & 50 & 4.44 & .972 \\
\hline Help to Stress Management & 50 & 4.76 & .517 \\
\hline Help for education & 50 & 4.70 & .544 \\
\hline Helpful to control children & 50 & 4.40 & 1.010 \\
\hline Helpful for good relationship & 50 & 4.56 & .812 \\
\hline Helpful for Business & 50 & 4.74 & .527 \\
\hline Helpful for Pregnant women & 50 & 4.54 & .862 \\
\hline Helpful for Professionals & 50 & 4.64 & .663 \\
\hline Essential to build Sonar Bangla & 50 & 4.46 & .930 \\
\hline Valid N (list wise) & 50 & & \\
\hline
\end{tabular}

Fig. 9: Level of Perception 
Analysis: Most of the people think there is no contradicts between mind management course and religion. Again they also think mind management courses are helpful for maintaining religion, stress management, education, relationship, controlling children behavior, business, pregnant women, different professional. But, most of the people prefer mind management courses for Stress Management (4.76). Moreover, they think to build SONAR BANGLA mind management course is imperative.

\section{Level of Preference}

\begin{tabular}{|l|c|c|c|}
\hline Descriptive Statistics & $\mathrm{N}$ & Mean & Std. Deviation \\
\hline Stress Management & 50 & $\mathbf{4 . 5 4}$ & .930 \\
\hline Goal Setting/Habit Control & 50 & $\mathbf{3 . 8 2}$ & 1.024 \\
\hline Headache Control & 50 & 2.62 & .855 \\
\hline Sleep Control & 50 & 2.06 & .793 \\
\hline Healing & 50 & 1.96 & 1.293 \\
\hline Valid N (list wise) & 50 & & \\
\hline
\end{tabular}

Fig. 10: Level of Preference

Analysis: This table is important for the mind management organization to design their products. This table expresses that most people prefer stress management, then Goal Setting/ habit control and then others. So, the mind management firm should concentrate to design products based on these two preferences.

\section{Level of Stress Management}

\begin{tabular}{|c|c|c|c|c|c|c|c|}
\hline \multicolumn{8}{|c|}{ Gender of respondent * Stress Management Cross tabulation } \\
\hline & & & \multicolumn{4}{|c|}{ Stress Management } & \multirow[t]{2}{*}{ Total } \\
\hline & & & Lowest & Medium & $\begin{array}{c}\text { Lower } \\
\text { Highest }\end{array}$ & Highest & \\
\hline \multirow{6}{*}{$\begin{array}{l}\text { Gender of } \\
\text { respondent }\end{array}$} & \multirow[t]{3}{*}{ Male } & Count & 2 & 2 & 6 & 31 & 41 \\
\hline & & $\begin{array}{l}\% \text { within gender } \\
\text { of respondent }\end{array}$ & $4.9 \%$ & $4.9 \%$ & $14.6 \%$ & $75.6 \%$ & $100.0 \%$ \\
\hline & & $\begin{array}{l}\text { \% within Stress } \\
\text { Management }\end{array}$ & $100.0 \%$ & $66.7 \%$ & $66.7 \%$ & $86.1 \%$ & $82.0 \%$ \\
\hline & \multirow[t]{3}{*}{ Female } & Count & 0 & 1 & 3 & 5 & 9 \\
\hline & & $\begin{array}{l}\% \text { within gender } \\
\text { of respondent }\end{array}$ & $.0 \%$ & $11.1 \%$ & $33.3 \%$ & $55.6 \%$ & $100.0 \%$ \\
\hline & & $\begin{array}{l}\% \text { within Stress } \\
\text { Management }\end{array}$ & $.0 \%$ & $33.3 \%$ & $33.3 \%$ & $13.9 \%$ & $18.0 \%$ \\
\hline \multirow{3}{*}{\multicolumn{2}{|c|}{ Total }} & Count & 2 & 3 & 9 & 36 & 50 \\
\hline & & $\begin{array}{l}\% \text { within gender } \\
\text { of respondent }\end{array}$ & $4.0 \%$ & $6.0 \%$ & $18.0 \%$ & $72.0 \%$ & $100.0 \%$ \\
\hline & & $\begin{array}{l}\text { \% within Stress } \\
\text { Management }\end{array}$ & $100.0 \%$ & $100.0 \%$ & $100.0 \%$ & $100.0 \%$ & $100.0 \%$ \\
\hline
\end{tabular}

Fig. 11: Level of stress management by Gender

Analysis: Male prefer more stress management than female. It shows that male people are in more tension state than female. So, it must be considered during product designing for stress management. 
Mind Management and Attitude Control

\begin{tabular}{|l|l|l|c|c|c|}
\hline \multicolumn{3}{|c|}{ Mind Management can change attitude * gender of respondent Cross tabulation } \\
\hline & & & \multicolumn{2}{|c|}{$\begin{array}{c}\text { Gender of } \\
\text { respondent }\end{array}$} & \multirow{2}{*}{ Total } \\
\hline & & & Male & Female & \\
\hline $\begin{array}{l}\text { Mind Management } \\
\text { can change attitude }\end{array}$ & Yes & Count & 41 & 9 & 50 \\
\cline { 2 - 5 } & $\begin{array}{l}\text { \% within Mind Management } \\
\text { can change attitude }\end{array}$ & $82.0 \%$ & $18.0 \%$ & $100.0 \%$ \\
\cline { 2 - 5 } & \% within gender of respondent & $100.0 \%$ & $100.0 \%$ & $100.0 \%$ \\
\hline Total & Count & 41 & 9 & 50 \\
\cline { 2 - 5 } & $\begin{array}{l}\text { \% within Mind Management } \\
\text { can change attitude }\end{array}$ & $82.0 \%$ & $18.0 \%$ & $100.0 \%$ \\
\cline { 2 - 5 } & $\%$ within gender of respondent & $100.0 \%$ & $100.0 \%$ & $100.0 \%$ \\
\hline
\end{tabular}

Fig. 12: Gender of respondent regarding Mind Management

Analysis: Everyone believes that proper Mind Management systems can alteration the attitude of the citizens which leads a peaceful and harmonious life.

\section{MAJOR FINDINGS}

The core analysis of Mind Management sector or industry of Bangladesh reveals the probable growing opportunity of it which is complied with the research. Major findings fo the study are depicted here:

- Cost (fees/charge) of the Mind Management course in Bangladesh between BDT. 5,000 to BDT. 9,500.

- Cost (fees/charge) of the Mind Management seminar is BDT. 500 to BDT. 2,000.

- Maximum Customer Choice Mind Management program for Stress Management.

- Maximum people want mind fitness center for managing their mind especially that are growing old.

- Government official, Employees, Students, and housewife, want mind fitness center more than private sectors and businessperson.

- Most of the people (66\%) think the relation between Mind and Body is Closer.

- Personal marketing approach (family, friends, and colleagues) is effective in this industry than TV or Radio Commercial.

- The age range of 31-40 spends the highest money for their mind management.

- Mass employees spend more money for their mind management for spiritual peace.

- Maximum people like to manage their stress through listening song and mediation or prayer.

- Most of the people think there is no contradicts between mind management course and religion.

- People also think mind management courses are very helpful for maintaining religion, stress management, education, relationship, controlling children behavior, business, pregnant women, different professional.

- Most of the people prefer mind management courses for Stress Management (4.54).

- Everyone believes that a proper Mind Management system can change the attitude of the citizens.

- Male prefer more stress management than female.

- Moreover, people think to build SONAR BANGLA mind management course is essential.

\section{RECOMMENDATION}

- The mind management firm should reduce their charge of their courses. Because the income level of the citizens should be considered. The Mind Management course charge huge amount of money so most of the citizen failed to bear beside their fundamental needs. 
- The service quality of the courses would be better. Quality is the first step of success in case of Service Business. The quality of service is the key to boost up the new industry to the people.

- As the mind management service is based on mind so psychological phenomenon should be considered. It is one of the sensitive issues. That's why, every Mind Management Firm should give special treatment in product design and operational procedures.

- The organization should focus on the age of 41-Above. Because people of this age are the main target people. In this stage people feel more stress in their whole life.

- The Mind Management Firms should give extra focus on women and especially pregnant women. Women are the mother of society. Not only that, they are bored for their daily life chores. Another side, pregnant women feel not better in their pregnancy period.

- The marketing system should be advanced. Still in Bangladesh Mind Management firms are lack behind in marketing when marketing is the bones of any firm.

- $\quad$ The Mind Management Firms should focus on interpersonal approach marketing. Because this business is depending on faith.

- Communication should be productive. Without effective communication the network of the customers can't be build. The Mind Management business is based on network and believes.

- The Mind Management service should be spread out all over the country. Now Maximum Mind Management firms are commercial and they are operating their programs in cities and big town not only that the branches are limited and small numbers. Mind Management is practice oriented. So, the Mind Management Firm should expand their operation all over the country.

\section{CONCLUSION}

To change Bangladesh, Mind Management is an imperative issue. If the people of the country can manage or control over their mind they will be more patience, more creative, more relaxed, and more productive, more earner and so forth. Again in recent there are many firms launched different mind management firm. Because there is a great chance to profit. So, it can be said that mind management service or industry is beneficial for the society and economic.

\section{REFERENCES}

Allport, G. W. and Murchison C. (1935), Handbook of Social Psychology Clark University Press.

Baum, A. \& Posluszny, M.D. (1999), Health psychology: mapping bio behavioral contributions to health and illness. Annual Review of Psychology, 50,137-163.

Hillson D. \& Webster R. M. (2006). What is Risk Attitude? Managing Risk Attitude using Emotional Literacy, 3. Retrieved July 22, 2014, from https:/ / goo.gl/QpnasV

Jose Silva (n.d.). Commentary. Retrieved July 22, 2014, fromhttps:/ / www.silvamethod.com/research/

Klinic Community Health Centre (2010, January). Sources of Stress. StressE Stress Management, 4. Retrieved July 22, 2014, from http:/ / hydesmith.com/de-stress/files/StressManagement.pdf

Klinic Community Health Centre (2010, January). Stress: What is it? StressE Stress Management, 3. Retrieved July 22, 2014, from http:/ / hydesmith.com/de-stress/files/StressManagement.pdf

Marc I, Toureche N, Ernst E, Hodnett ED, Blanchet C, Dodin S, Njoya MM (2011),Mind-body interventions during pregnancy for preventing or treating women's anxiety. John Wiley E Sons Publication. 2

Meditation (n.d.). Commentary. Retrieved July 19, 2014, from https:/ / en.wikipedia.org/wiki/Meditation

Psychoneuroimmunology (n.d.). Commentary. Retrieved July 19, 2014, from https://en.wikipedia.org/wiki/Psychoneuroimmunology

Quantum Method Meditation Course (n.d.). Commentary. Retrieved July 20, 2014 from http://www.abc-ofmeditation.com/asia/bangladesh/dhaka/quantum-method-meditation-course.asp

Silva Method (n.d.). Commentary. Retrieved July 20, 2014 from https://en.wikipedia.org/wiki/Silva_Method

Silva Method (n.d.). Commentary. Retrieved July 22, 2014, from https:/ / www.silvamethod.com/ 


\section{APPENDIX}

Questionnaire for Collecting Data on "A Comprehensive Study on Prospective Mind Management Sector in Bangladesh"

Following Questionnaire has been prepared to collect data on Prospective Mind Management Sector in Bangladesh. Please tick the appropriate boxes according to your preferences for each of the following questions. Your information will be kept confidential and used only for academic purpose. It would take 3-4 minutes of your 24 hours but certainly will save me from lot of road works.

(Please tick your choice)

Part: 01

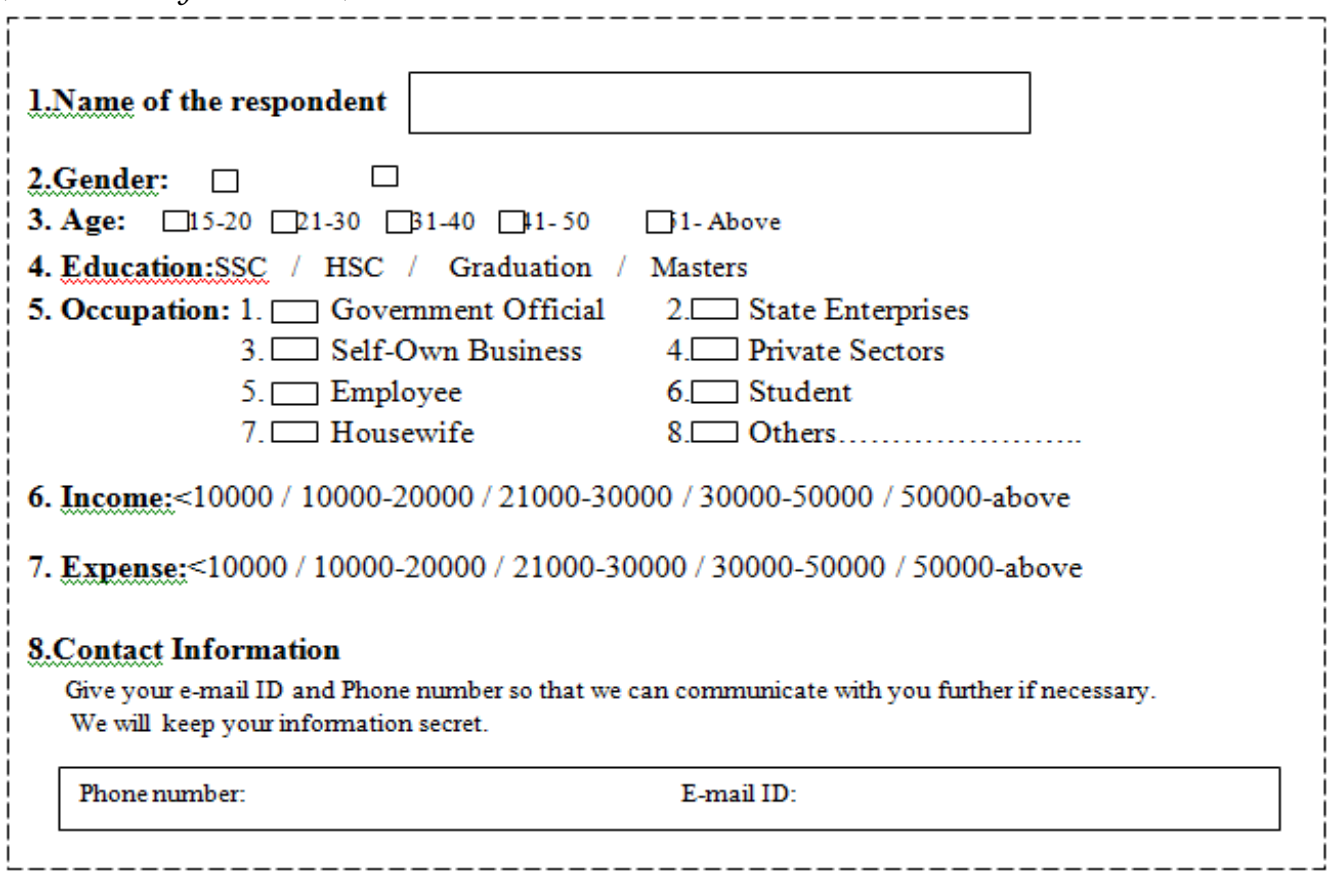

Part: 02

9. How close do you feel the relation is, between Mind and Body? $\square$ Distant $\square$ Edge $\square$ Middle $\square$ Closer

10. Have you any Mind Management Course?

$$
\square \text { Yes } \square \text { No }
$$

11. Do you think we need Mind Fitness Centers?

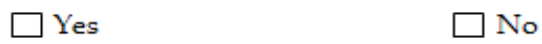

12. What Types of Tools you use to manage Stress?
$\square$ Listen Song
Sleep
$\square$ Gossip
Destructive activities
$\square$ Meditation
Others

Tight

13. Do you think Mind Management can change the attitude of the citizens of Bangladesh?
$\square$ Yes
$\square$ No

14. How much money you spend to manage your mind in a month?

15. Why are you using Quantum/Silva/Creative Meditation Method for your mind control? 
16. Where did you first hear about Mind Management Course?

$\square$ Press Advertisement $\square$ Television Commercial $\square$ Face book $\square$ Billboards

$\square$ Family members / Relatives / Friends / colleagues / co-worker

$\square$ other.

17. How frequently do you use Mind Control Techniques in a day?

$\square 1$ time in a day
$\square$ 2-3 times in a day
$\square$ 3-4 times in a day
$\square$ Above 4 or..........

18. Please indicate your perceptions about different Mind Management Course in BD.

\begin{tabular}{|l|c|c|c|c|c|}
\hline & $\begin{array}{c}\text { Strongly } \\
\text { Disagree (1) }\end{array}$ & (2) & (3) & (4) & $\begin{array}{c}\text { Strongly } \\
\text { Agree (5) }\end{array}$ \\
\hline Contradicts to religion & 1 & 2 & 3 & 4 & 5 \\
\hline Cooperates to maintain religion & 1 & 2 & 3 & 4 & 5 \\
\hline Useful for Tension/ Stress Management & 1 & 2 & 3 & 4 & 5 \\
\hline Helpful for Teaching and Education & 1 & 2 & 3 & 4 & 5 \\
\hline Helpful for Controlling Children & 1 & 2 & 3 & 4 & 5 \\
\hline Helpful for maintaining a sound relationship & 1 & 2 & 3 & 4 & 5 \\
\hline Helpful for Business \& Motivation & 1 & 2 & 3 & 4 & 5 \\
\hline Helpful for Pregnant women & 1 & 2 & 3 & 4 & 5 \\
\hline Helpful for different Professional & 1 & 2 & 3 & 4 & 5 \\
\hline $\begin{array}{l}\text { It is essential to change the attitude of people } \\
\text { of the country to build SONAR BANGLA. }\end{array}$ & 1 & 2 & 3 & 4 & 5 \\
\hline
\end{tabular}

19. Rank the following task according to your preference.

( 1 for lowest \& 5 for highest, you can weight once at a time)

\begin{tabular}{|l|l|}
\hline Stress Management & \\
\hline Goal Setting & \\
\hline Headache Control & \\
\hline Sleep Control & \\
\hline Healing & \\
\hline
\end{tabular}

20. Rate your level of satisfaction with the overall Mind Management services in Bangladesh?

\begin{tabular}{|c|c|c|c|c|}
\hline $\begin{array}{c}\text { Very } \\
\text { dissatisfied }\end{array}$ & $\begin{array}{c}\text { Somewhat } \\
\text { dissatisfied }\end{array}$ & $\begin{array}{c}\text { Neither satisfied } \\
\text { nor dissatisfied }\end{array}$ & $\begin{array}{c}\text { Somewhat } \\
\text { satisfied }\end{array}$ & $\begin{array}{c}\text { Very } \\
\text { satisfied }\end{array}$ \\
\hline 1 & 2 & 3 & 4 & 5 \\
\hline
\end{tabular}

21. Do you have any Opinion/Suggestion on Mind Management service? If yes, please write it down. 